\title{
Social Value Creation in Art-Related Tourism Projects: The Role of Creative Project Actors in Diverse National and International Settings
}

\author{
Kotaro Nakamura \\ Japan Advanced Institute of Science and Technology - eCraft Inc., Japan \\ knakamura@ecraftjapan.com
}

Hideyuki Sakamoto

School of Interior \& Architectural Design, Kanazawa College of Art, Japan

sakamoto@kanazawa-bidai.ac.jp

Dejan Križaj

University of Primorska, Faculty of Tourism Studies - Turistica, Slovenia

dejan.krizaj@fts.upr.si

To clarify the role of art and artists as creative actors in art-related tourism projects, the study focuses, from the perspective of social value creation, on art projects that are in the development stage and that aim to promote local sustainability. We propose a framework for comprehensive understanding the social value creation in terms of the service-dominant logic (SDL) theory. The framework applies eleven attributes organised in four (why-who-what-how) categories to obtain six kinds of insight into the project actors' network ecosystem. The framework is applied to case studies from Japan: the 'Kanazawa Creative Tourism' (Кст) project in a cultural-heritage city, the 'Kinokuni Train Art' (ктA) project along a railway line running through a coastal area with rich natural resources, and similar projects in Slovenia. Through stakeholders' interviews, field surveys and theoretical research we analyse and compare these projects in terms of the attributes of the proposed framework. The study provides insights towards identifying the major types of creatively involved actors of art-related tourism projects: mostly local artists and craftsmen, but also members involved mainly as collaboration generators and intermediaries operating at different integration levels. To validate the framework's destination management insights in a broader international background, we refer in the discussion to similar examples with different cultural and geographical backgrounds and/or maturity level from Slovenia, an EU country.

Keywords: tourism, art projects, SDL, resource integration, value co-creation https://doi.org/10.26493/2335-4194.10.191-203

\section{Introduction and Method}

The number of art projects in Japan has reached about 200 , from freshly launched local-level events to largescale festivals over wider regions, already bearing eco- nomic results. This reflects the ongoing change of contemporary arts: the creative style of artists attaches importance to participant interaction and extends art activities beyond the simple creation of artworks to- 
wards the social practices and networking of 'socially engaged art' (Helguera, 2011).

Two recent examples are the Setouchi Triennale 2016 and the Echigo-Tsumari Triennale 2015. The Setouchi Triennale is an art project taking place on 12 islands in Japan's Seto Inland Sea, focused on food and other local projects conveying regional culture 'connecting with Asia and the World via the sea' (Setouchiartfest, 2017). The Echigo-Tsumari Triennale is held in a snowy rural region and has been pursuing the integration of natural and cultural resources through art creation staged at local farms, houses, and museums (Kitagawa, Breslin, \& Fravell, 2015; Echigo-tsumari, 2017). These large-scale art projects attracted 1.04 and 0.5 million visitors and had an estimated economic effect of 14 and 4.6 billion yen, respectively. In the case of Setouchi Triennale 2016, 2.6\% of visitors were foreigners.

Hopes are high that art projects will bring regional innovation and create social value towards solving social problems by mobilising and integrating art-related regional resources. Tourism based on such resources attracts outside visitors and contributes to overall business sustainability.

In this paper, art is not limited to general art forms but is meant to include all kinds of creative activities taken up and all kinds of products made in various art projects. Social value creation in art projects (abbreviated as 'svCA' in this paper) is a cross-sectoral issue involving art, service, tourism and innovation, and its comprehensive understanding requires examination of the role of arts and artists in SvCA. However, an approach that would bring generalised knowledge on this role has not been sufficiently pursued (Nakamura, 2013). Thus this research aims to answer the important questions of what kind of structure of art-mediated tourism would better advance the (co-)creation of social value and what kind of roles art and artists should play as 'creative actors' to obtain better resource integration. The case studies evaluate tourism innovation stemming from the integration of regional resources and the value co-creation among art tourism project actors.

The paper first discusses the theoretical background of art-related tourism from the viewpoint of
SVCA in the second section. The third section presents two case studies in Japan, which are then analysed and compared in the fourth section. The fifth section summarises the SVCA insights, followed by the sixth section, which introduces similar Slovenian art-tourism cases and discusses the relationship with tourism, and conclusions in the seventh section.

\section{Theoretical Background}

\section{Social Value Creation in Art-Project-Related Tourism}

Art projects are intended to create social value, such as contributing to communities' sustainability and generating economic value through collaborative activities of regional stakeholders pursuing the realisation of cultural value (Throsby, 1994; Prahalad \& Ramaswamy, 2004). This research focusses on the value triad of social, economic and cultural (aesthetic) value (Makiguchi, 1964; Throsby, 2001). 'Creating shared value, which has been the focus of much attention recently, can be said to reconcile economic and social value (Porter \& Kramer, 2011). Also in tourism, pursuing social value has become indispensable for achieving sustainability of natural and cultural assets (UNESCO, 2017).

Tourism related to art projects can be recognised as a kind of cultural event tourism, and their study is a field at the nexus of tourism and event studies (Getz, 2008). Especially with art project events, art is expected to systematically improve the competitiveness of tourism via the benefits of culture-based creativity (Korez-Vide, 2013). As one director of a successful Japanese art project from our surveys observed, art is positioned to clarify the human-nature and humanculture relationships in regional ecosystems (Kitagawa et al., 2015).

Art-project-related tourism can also be interpreted in terms of the service ecosystem concept, which is central to dominant service logic (SDL) analysis (Barrett, Davidson, Prabhu, \& Vargo, 2015). In the service ecosystem, organisers and artists act as operant resources (Vargo, Wieland, \& Akaka, 2015) and cooperate with other actors to integrate regional resources to achieve mutual value co-creation (Vargo \& Lusch, 2015) towards providing unique experiences for visitors (Stickdorn, 2014). 


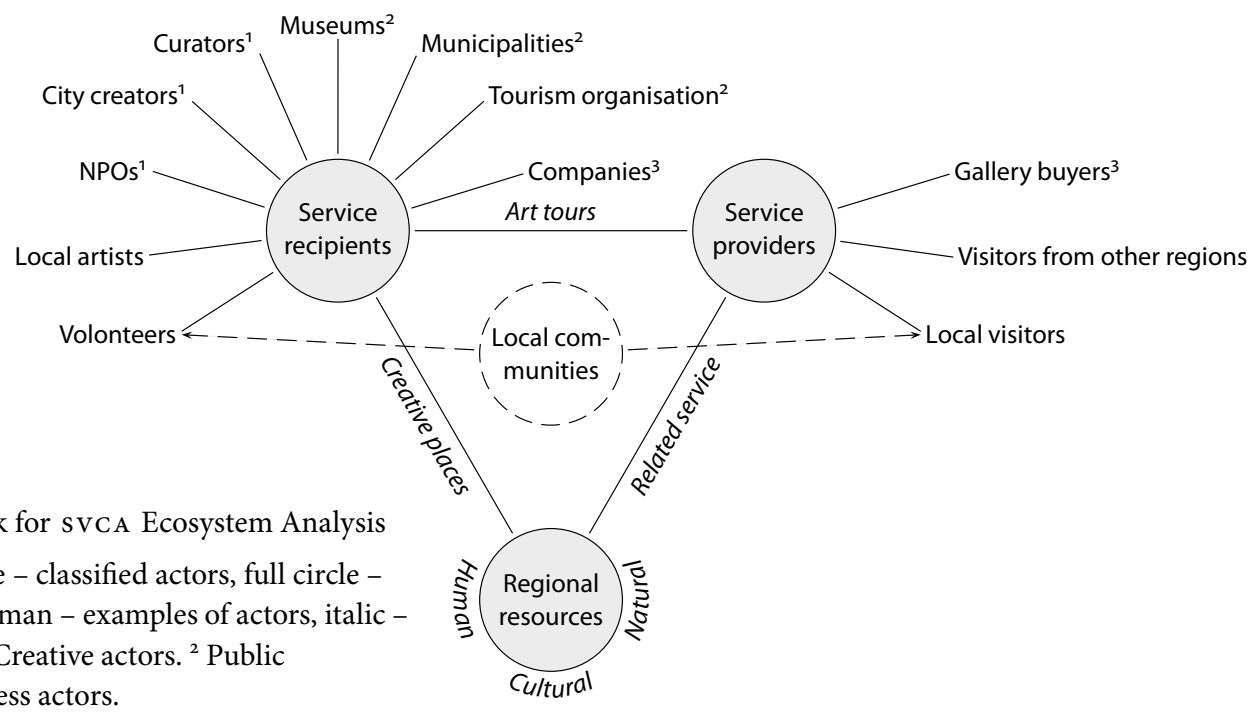

The various actors of art projects integrate further regional resources to expand the service ecosystem through networking aimed at regional innovation (Vargo et al., 2015) and new smart tourism destinations (Boes, Buhalis, \& Inversini, 2016). According to our observation of Japanese art-tourism projects, the actors in the ecosystem of SVCA described in the first section include not only art-related people and public organisations but also people and businesses with no direct involvement with the arts in the regional community (Maciver \& Page, 1949). Local people’s participation is important for SVCA outcomes especially in rural areas, because local communities are the base of SVCA in the mobilisation and integration of regional resources (Mair, Robinson, \& Hockerts, 2006; Rasoolimanesh, Ringle, Jaafar, \& Ramayah, 2017). Particularly in SVCA, the diversity of actors and resources is essential for the development opportunities of the service ecosystem (Letaifaa, Edvardsson, \& Tronvollc, 2016).

\section{Framework for Insight of SVCA Ecosystem}

Based on the above considerations, we propose the framework for SVCA ecosystem analysis shown in Figure 1. It is an upgrade of the 'service ecosystem' concept, reflecting the specifics of art-related tourism and expresses the actor-to-actor network involved (Lusch \& Vargo, 2014). From a narrower tourism-service view, it is a relationship of service providers, service recip- ients, and related resources, organised in a tourism service network (Shirahada \& Fisk, 2013).

However, when expanding the view to the wider surrounding service network, attention focusses on the role of more actors of different types. svCA actors can be classified in the following four sectors (Peng \& Lin, 2016):

- creative actors: people of the arts and culture with creative activities,

- business actors: individuals and private businesses involved in tourism and/or art and as visitors,

- public organisations: local governments, museums, tourism and other associations, etc.,

- local community: the local residents and bearers of regional activities.

As will become clear from our examples, in different projects different sectors play the leading role. Each actor is included in the SVCA ecosystem with links to one or more of the above four sectors. Service value is created through the resource integration of local human, cultural, and natural resources, adding new individuals and public entities to the local market economy (Lusch \& Vargo, 2014). Each actor engages at various service levels (from operating resource to operators) with one or more other actors as providers of creative venues, guided tours, related services, etc., which become interaction points of value co-creation (Vargo \& Lusch, 2004). 
Table 1 Case Study Attributes and Insight Points for Svc A Analysis

\begin{tabular}{llll}
\hline Why & Who & What & How \\
\hline Demand & Leader \& & Type of event & Promotion center \\
Innovation via art & Organisational form & Duration \& frequency & Communication with others \\
& Partners & Art spots & \\
& Funding sources & & \\
\hline Insight points & Ecosystem & Interactive venues & Regional resources \\
& Leading parties & Values for main actors & Outcomes \\
\hline
\end{tabular}

Table 2 Outline of the Kanazawa Creative Tourism (кст) project

\begin{tabular}{|c|c|}
\hline Sponsors & $\begin{array}{l}\text { Non-Profit Organization (NPO) Kanazawa Creative Tourism Promotion (under N Po Kanazawa Art } \\
\text { Group). }\end{array}$ \\
\hline Mission & $\begin{array}{l}\text { To preserve the cultural heritage and environment of the old town in Kanazawa and to sustain the life } \\
\text { of craftsmen and artists through promoting creative tourism under the Creative city brand with the 21st } \\
\text { Century Museum of Contemporary Art (called } 21 \text { Art by locals). }\end{array}$ \\
\hline Co-sponsors & NPo Kanazawa Art Group, NPo Suito Kanazawa, Noetica Inc., 21 Art, the city's art galleries. \\
\hline Timeline & $\begin{array}{l}\text { 2004: The } 21 \text { Art museum opened. The museum's vision emphasised the city's open spaces as an 'art } \\
\text { museum open to the city like a park.' However, there was not enough flow from the museum's } 1.5 \text { mil- } \\
\text { lion/year visitors to the city. } \\
\text { 2009: Kanazawa city designated Creative City in the category of Crafts and Folk Art by UNEsco. The } \\
\text { city has many art and craftwork ateliers, galleries, tradesmen, etc., but information centralisation was } \\
\text { not sufficient, so that there was a need to prepare easy to understand visitor information. Prompted by } \\
\text { UNEsCo's Creative City designation, NPO Art Group discussed the 'creative tourism' concept on the } \\
\text { example of the Us city of Santa Fe and decided to establish the Kanagawa Creative Tourism project. }\end{array}$ \\
\hline Start & $\begin{array}{l}\text { The кст project was launched in 2008. The 'Cycle-de-Art' project was started in } 2009 \text { as a social exper- } \\
\text { iment with the concept of a 'rent-a-bicycle service suitable for touring the city's art spaces. Following the } \\
\text { example of foreign cities' community cycling, original fashionable rent-a-cycle was made available. Start } \\
\text { of related services, such as distribution of cycling maps introducing the city's art spaces, and 'Pedal Day' } \\
\text { guided tours? }\end{array}$ \\
\hline Website & http://tour.artgummi.com \\
\hline
\end{tabular}

\section{Methods}

\section{Case Analysis}

The basic analytical approach follows the arguments of Hamel (2006) and organises the SvCA attributes in the four groups of Why, Who, What, and How (Krizaj \& Horvat, 2015). The Why group identifies the demands which the social value creation in each project and the participating creative actors seek to answer. The Who group focuses on the major project actors and on the form of organisation in each case. The What group addresses the contents of each project including art and artistic elements. Finally, the How group identifies the ways of promotion and communication with visitors and stakeholders. We propose eleven attributes, as shown in the upper part of Table 1 , as a basis for analysing SvCA projects. These attributes are used later in the paper for comparative analysis by explanatory description (Eisenhardt, 1989; Yin, 2009; Callaway \& Dobrzykowski, 2009) by discussing case studies from Japan and Slovenia. For each case study, all attributes are described individually and in their relationship, with a focus on examining the role of the participating creative actors.

Based on this primary Why/Who/What/How analysis, the project's SVCA ecosystem is considered as outlined in the second section, and its dynamic development is examined, with regards to the following six insight points: 
Table 3 Outline of the Kinokuni Train Art (ктA) Project

\begin{tabular}{|c|c|}
\hline Sponsors & Kinokuni Train Art Executive Committee (under the umbrella of Tanabe City Chamber of Commerce). \\
\hline Mission & $\begin{array}{l}\text { To create high-value artworks by discovering local resources. To collaborate with Japan Railways (JR) } \\
\text { Kinokuni Line and the communities around its more than } 30 \text { station buildings in operation and pro- } \\
\text { motion of 'art trains', aiming at the regional prosperity of the more than } 10 \text { towns along the line through } \\
\text { attracting guests from outside the region. }\end{array}$ \\
\hline Co-sponsors & $\begin{array}{l}\text { Collaborated by JR West Wakayama Branch. Support: Wakayama prefecture and local administrations, } \\
\text { boards of education, chambers of commerce, NPOs, Rotary clubs, around } 50 \text { local businesses and indi- } \\
\text { viduals. }\end{array}$ \\
\hline Timeline & $\begin{array}{l}\text { A local art event organised by artist Naoko Hiromoto evolved into the 'Art Tanabe 2013' festival. } 29 \\
\text { artists participated in } 7 \text { venues centred at the former city library. } \\
\text { In 2014, by collaboration with JR West, it grew from small exhibitions in the station buildings to special } \\
\text { trains, including JR campaigns '10 Years World Heritage.' }\end{array}$ \\
\hline Start & $\begin{array}{l}\text { The KTA project was launched in } 2014 \text { with the theme of 'Symbiosis with local communities.' In } 2015 \\
\text { the regional collaboration with JR expanded: permanently displayed art increased, there was more co- } \\
\text { ordination with regional events in the major stations, JR issued special touring tickets including an art- } \\
\text { designed train. }\end{array}$ \\
\hline Website & http://trainart.jp/ \\
\hline
\end{tabular}

- Ecosystem: which sectors and actors (creative actors, public organisations, business actors, local communities) play a major role in forming the ecosystem?

- Leading party: Which sector and who among the actors plays the leading role for SvCA?

- Interactive venues: what kind of potential venues for interaction among actors in various events exist (creative places/art tours/related services)?

- Value for main actors: What value is co-created for each project actor?

- Regional resources: Which regional resources are integrated into the SVCA?

- Outcomes: What outcomes are brought out by the results of SVCA?

To summarise the SVCA analysis framework introduced up to now, the analysis attributes and points for insight sought are shown in Table 1.

\section{Case-Study Selection}

The projects chosen as case studies were selected considering the following points, which we believe are important for clarifying the role of art and creative activities for SvCA.
- The cases were to cover widely differing cultural, natural and human resources situations, permitting examination of the reflection and role of art.

- The cases were to be still in the developing stage to enable the study of dynamic processes in artproject-related tourism in transition.

In this study, the following two Japanese projects for case studies have been selected:

1. Kanazawa Creative Tourism (abbreviated кст)

2. Kinokuni Train Art (abbreviated KTA)

The detailed information of both cases is shown in Tables 2 and 3. Furthermore, insights from art-related tourism projects in Slovenia are included in the discussion of the sixth section and compared to the Japanese examples.

\section{Outline of the Kanazawa Creative Tourism Project}

Kanazawa Creative Tourism (КС T) is a creative tourism project (OECD, 2014) that takes place mainly in spring and autumn in the town surrounding old castle of Kanazawa city, having its central office based at a local art centre. Organizers offer guided tours customised to guests' requests, including visits to workshops of craftsmen and artists and to the traditional townhouses and gardens where they work, which are 
Table 4 Demand and Innovation via Art

\begin{tabular}{lll}
\hline Project & Demand & Innovation via art \\
\hline KC T & $\begin{array}{l}\text { Attracting visitors to downtown of cultural heritage } \\
\text { city }\end{array}$ & Learning experience \& chances for appreciation \\
\hline K TA & Visitors to local destinations in rural area & Site-specific art experience \& creative venues \\
\hline
\end{tabular}

all open to the public for the event. The main purpose of the project is preserving the cultural heritage and environment of the old town and sustaining the life of craftsmen and artists working there. A further goal is increasing the recognition among culture fans and patrons of Kanazawa-city as a city certificated in 2009 as a member of UNESCO's 'creative city network' in the traditional crafts category, a certification achieved after the opening of the 21st Century Museum of Contemporary Art there. Кс т was launched by full-time museum service staff struggling to cope with rising visitor numbers after the start of the new Shinkansen (bullet train) service from Tokyo in 2016.

\section{Outline of the Kinokuni Train Art Project}

Kinokuni Train Art (к тА) is an art project along the Kinokuni railway line running more than $100 \mathrm{~km}$ along the southern coast of Japan's rural Kii peninsula. The project features art events taking place for about a month, mainly in autumn, including a three-day main event. With few exceptions of larger cities, the railway has many small old unmanned stations in beautiful locations. Each year the project' organisers plan 'train art' events timed around the days of the special train tours and focusing on artwork created by local artists using each stations' spaces (wall paintings or art displayed at the stations). On art-train days a colourfully designed train travels between the terminal stations staying at each intermediate artwork-decorated station for short art events. The main purpose of the project is to present opportunities for creative activities towards the revitalisation of localities and communities along the railway line. $\mathrm{K} \mathrm{TA}$ is determined to continue until at least 2020 to achieve their goal of the 'Kinokuni line as the world's first art railway'.

\section{Survey Methods}

Our methods of the survey included, (a) interviews with key-persons and participants, (b) field studies, and (c) follow-up surveys and examination of related publications mainly towards obtaining qualitative data for case study and insight for SVCA analysis.

In the case of кСт, we performed an in-depth interview (Kvale, 2007) with one of the executive managers in the spring of 2015. Previously, in 2014, we participated 16 times in various art tours as observers, in the course of one year of multiple meetings. Furthermore, we conducted systematic interviews with artists and project members after a related symposium about $\mathrm{KC} \mathrm{T}$ in the spring of 2017 .

As to KTA, our survey included in-depth interviews with the leading artist among the organisers and with the manager of the main collaborating NPO, as well as systematic interviews at the end of the KTA 2014 and 2015 events (two artists, one local businessman, and one volunteer). After that, we observed the participants and the actual flow of the project for a total of 13 times during 2015-2016. These field observations were followed by a survey of mainly e-mail questionnaires to artists, active supporters and related businesses ( 6 questionnaires returned in the autumn of 2015). The survey provided qualitative data from the entire $100-130 \mathrm{~km} \mathrm{KTA}$ project field area along the railway line.

\section{Results: Projects' Attribute Analysis \\ Why}

The attributes of the Why group address the demand for SVCA, as shown in Table 4. Such demand is answered by the features of the particular art tourism projects and by cooperation among the creative actors (artists and craftsmen).

КСТ answers a social demand for sustaining historic townhouses and the life of craftsmen and artists working there. The local art museum with its concept of 'art museum opening to the city' has been aiming at more links to the city's artists and galleries as potential resources. Thus, кст aimed to direct part of the 
Table 5 Leadership and Organisation

\begin{tabular}{llll}
\hline Project & Leader \& organisational form & Partners & Funding sources \\
\hline KCT & Creative tourism promotion in- & $\begin{array}{l}\text { Artists/group of city planners city } \\
\text { museum of contemporary art. }\end{array}$ & Public and private capital \\
\hline \multirow{2}{*}{ KTA } & Art project committee including & $\begin{array}{l}\text { Railway company \& local busi- } \\
\text { active young artists }\end{array}$ & Public and private capital \\
& & organisation. & \\
\hline
\end{tabular}

Table 6 Art Project Content

\begin{tabular}{llll}
\hline Project & Type of event & Duration \& frequency & Art spots \\
\hline KCт & Tours on demand with art fair & Mainly in spring/autumn & Open ateliers: 30 registered spots: \\
& & & 40 \\
\hline KTA & Seasonal events & One month per year, including a & Artists: 42, art spots: $35+$ (including \\
& & 3-days main train-art event & 27 railway stations) \\
\hline
\end{tabular}

great number of museum visitors ( 1.5 million in 2015) to the downtown of the old cultural heritage city. In doing so, the project provides for visitors a chance to get new learning experience at artwork venues, and for artists, a chance to have their work appreciated and turned into a source of revenue.

KTA is driven by the demand for regional revitalisation along the railway line. The project hopes to establish a sense of unity among not only public and private organisations but also among residents, visitors, and business stakeholders. To achieve this, к T S organisers have joined hands with local communities and railway company staff to organise events for young artists using the railway facilities as creative venues. Another aim is to provide attractive tourism options for visitors interested in 'site-specific art' experience.

\section{Who}

The Who group of attributes identifies the major individuals and organisations leading the projects, their individual and organisational partners, and the origins of capital, as summarised in Table 5.

кСт has been directed by nPo Kanazawa Creative Tourism Promotion (NPO: Non-Profit Organisation). It consists of leading college professors, craftsmen and artist groups, curators at art museums. NPO Kanazawa Art Group acts as secretariat, while NPO Suito Kanazawa and Noetica Corp. provide auxiliary support. The collaborative network includes the city's art galleries inspired by the example of the city of Santa Fe in the United States. кст activities are performed jointly with the Shared Workshops Commission (swc) that provides low-cost atelier space in the city for nurturing young artists. Another partner is Cycle-de-Art Corp. (CDA), a provider of rent-a-cycle service for personal transportation. КС $\mathrm{T}$ was initially sponsored by the Japanese Agency for Cultural Affairs, later joined by a regional construction association.

K TA was launched by a female artist, who at the time had just come back from France. The project is now directed by the Kinokuni Train-Art Committee, which includes active local artists. Japan Railway West Inc. is the project's major partner by providing operational support and free use of station facilities. Other K TA partners include volunteering operation staff, regional businesses, local tourist associations, educational organisations such as local high schools, etc. KTA is sponsored by more than 10 local municipalities, several NPOS, and about 50 local businesses and individuals.

What

The What group of attributes shows the content of each art project, including the type of events, duration and frequency, and the kind and numbers of art spots, as summarised in Table 6.

KCT mainly conducts guided tours at the request of visitors with appointments, especially during the art 
Table 7 Marketing

\begin{tabular}{lll}
\hline Project & Promotion center & Communication with others \\
\hline KCT & Art centre office & Website, social media, events \\
\hline KTA & City chamber of commerce office & Same as above, traditional media (via railway company) \\
\hline
\end{tabular}

Table 8 Ecosystem and Driving Actors

\begin{tabular}{lll}
\hline Project & Ecosystem & Leading parties \\
\hline KCT & Creative individuals and public organisations & $\begin{array}{l}\text { Art leading organisations/NP Os as promoters of the } \\
\text { creative-city concept }\end{array}$ \\
\hline KTA & $\begin{array}{l}\text { Urban creative individuals, business actors and } \\
\text { local communities }\end{array}$ & $\begin{array}{l}\text { Autonomous artists supported by railway company and } \\
\text { local communities }\end{array}$ \\
\hline
\end{tabular}

fair in the cultural city. Guided tours started in 2009 and take place mainly in spring and autumn. Until now 30 open ateliers/workshops and 40 art spots have been registered. The guided tours include visits to open studios of various ateliers and even to places usually not open to the public.

Since $2014 \mathrm{KTA}$ has been conducting the project as a seasonal event and has decided to continue until at least 2020. The events span over one month and include a special train-art main event running for three days every year as an extension to usual express trains. More than 40 artists have joined the project with 42 art spots including 27 railway stations along the more than $100 \mathrm{~km}$ long rail line. Art collaboration workshops attended by residents and visitors include drawing local sea fauna, woodblock painting, making furniture from disposed lumber, etc. Experience events are also popular: live painting, music performances (including jazz sessions with high school bands), tea ceremony with woodblock printing, making Christmas ornaments etc.

\section{How}

The How group identifies the promotion centre and the communication channel with visitors and stakeholders, as summarised in Table 7 . In Кс $\mathrm{T}$, the office and exhibition corner of the Art Center located in the gathering hall of the central railway terminal of the city take the role of tour promotion and manage communication. In к TA, the headquarters is officially located in the local Chamber of Commerce office. A leading artists' N PO group together with the railway company maintain advertising and the relationship with other local organisations.

\section{Insights from the Japanese Cases}

Tourism Service Ecosystem and Projects'

Leading Parties

The tourism service ecosystem underlying the projects and the leading parties of the respective SvCA frameworks are summarised in Table 8 . They evolve dynamically with time in response to changing needs and conditions.

In $\mathrm{KC}$, the project participants initially shared the ambition of city promoters to produce new value fitting to the 'Creative City' concept. The project evolved while being directed by individual activists, such as university professors, architects/designers and city/ community planners. Then the project was formalised under public organisations such as the city art museum and the creative city committee. At the operational level, that was followed by active artists/craftsmen engaging as planning and management staff. The КС т project also relies on the participation of visitors, art fans and patrons as active actors interacting with artists in their working places (ateliers/studios), an interaction that is not possible in art museums.

In KTA, the art project was initiated by autonomous artists and supported by a railway company and local communities. Initially, the interest from local municipalities and residents was not high. However, the mood of cooperation arose through the interaction of artists with the local communities around the stations. For example, local people began to appreciate 
Table 9 Interaction Venues and Value for Each Actor

\begin{tabular}{lll}
\hline Project & Interactive venues & Values for each actor \\
\hline KCT & (a) open studios, (b) guided tours, & For visitors: experience value with arts \\
& (c) related services (concierge, rent-a-cycle) & For artists: revenue and chance to get appreciation \\
\hline \multirow{2}{*}{ KTA } & (a) creative places, (b) train tours, & For visitors: experience value with arts \\
& (c) related artistic events & For young artists: carrier step-up \\
& & For railway: more guests and image boost \\
\hline
\end{tabular}

Table 10 Regional Resources and Outcomes

\begin{tabular}{lll}
\hline Project & Regional resources & Outcomes \\
\hline KCT & Artisans/craftsmen, old townhouses & Visitors: not only art fans but also experts (architects \& \\
& & researchers), extended city popular and more city fans \\
\hline \multirow{2}{*}{ KTA } & Old station buildings, coastal landscape & Visitors: train passengers 600+ \\
& & Event participants: $100-500$ per event \\
& Participating local business: reached 30+ \\
\hline
\end{tabular}

the project's significance by observing artwork activities gradually cleaning up the station facilities. Then local people began to participate in the collaboration workshops, as described above. On the other side, the railway company continued to affirm their support for the artists' activities at the stations and spread the railway operators' pride of turning 'Kinokuni line into the world's first art railway' beyond the railway sections in the project's area.

\section{Interaction Venues and Value for Each Actor}

Interaction venues and the kind of value co-created for each participant are summarised in Table 9. The кст project uses mainly three types of venues for actors' interaction: (a) Open studios extend visitors perception of the city as a whole. They benefit artists, too, with many new connections among themselves having been established. (b) Guided tours promote deeper recognition of local cultural resources. (c) Art-tourism related services include not only public organisations such as museums but also supporting businesses such as lodging facilities. For example, a concierge service providing art-tour escorts contributes to wider networking for the artists by inviting famous gallerists and curators from the metropolitan area. In such a way, interaction at the project's venues co-creates experience value for visitors, while artists and craftsmen have the opportunity to receive appreciation.
The к TA project, too, has already developed active collaborative interaction: (a) at creative venues mostly between artists and participating local residents, (b) in train tours mostly between artists and art patrons, and (c) at the accompanying events between KTA's project operators, railway staff and local businesses and organisations. With the background of stations and beautiful scenery along the line, lively communication has emerged using various types of arts as a medium. For the mostly young artists, taking part in the events sponsored by the railway company is a useful carrier step as socially engaged art. At the same time, visitors benefit from enjoying unique experience value through such 'site-specific art.' The railway company confirmed that the artists' support brought the results of attracting more guests and boosted the pride of the rail-line operators.

\section{Regional Resources and Outcomes}

The regional resources integrated for SVCA and the outcomes resulting from such integration are summarised in Table 10.

КСт activities reaffirmed artisans/artists and old townhouses as important regional resources archiving and sharing valuable knowledge. The кст events attract not only general art fans, but also expert groups of architects and researchers, whose activities afterwards further extend the popularity of Kanazawa-city 
as a cultural heritage city and attract new fans. A potential current issue is building a business model that meaningfully distinguishes the project from guided services conducted by other business actors for wealthy art collectors from foreign countries.

$\mathrm{KTA}$ activities promote the integration of old station facilities and beautiful coastal landscape as resources for artwork and its appreciation and for the unique experience of train-art. The need for cooperation in the process of planning and running projects along the railway linking major and unmanned stations gradually enabled new 'gap-bridging connections' among localities and organisation divisions extending beyond previous limits. Each art train event brings 600 to 1000 train passengers with $100-500$ visitors participating in each of the related events, and the number of local business involved has reached about more than 30 . There is room for more advanced director and producer's role in $\mathrm{KTA}$ to achieve a better regional balance between autonomous artists' activities and the demand of local businesses and other actors.

\section{Comparative Conclusions for the Japanese Cases}

A common characteristic manifested in all insights derived above is the tourism-art projects' reliance on the collaboration of creative actors, such as artists and craftsmen, with some partners (e.g. museum or railway company), in which some of the participants take the more active role of collaboration generators and intermediaries in the running of art-project-related tourism. However, different levels of involvement in driving the underlying SVCA resource integration can be identified.

This reflects the difference between a strategic project towards the promotion of a Creative City image based on traditional cultural heritage, as found in the KC T project, and a community project using regional resources to revitalise a depopulating countryside region, as manifested in the KTA project. In KCT, the artists themselves perceive the potential of regional resources towards achieving sustainability (Anderson et al., 2013). Accordingly, the interaction with visitors is focused on guided tours. As to the к тА project, residents' participation in creative venues around the stations, even on the days without train tours, has more weight. Thus, in $\mathrm{KC}$, the main SvCA role of art and artists is to be an 'intermediator' for creative city branding, while in K TA the role is more of an integrator' of regional resources for co-creation of aesthetic value for all participants.

\section{Discussion Beyond the Japanese Context}

In the quest to understand, position and evaluate Japanese cases in the scope of similar cases with different international backgrounds, we have analysed three art and culture tourism related examples from an $\mathrm{EU}$ member country, Slovenia.

\section{Art Tourism Planning in Ljubljana}

In the first case, we interviewed Ljubljana Tourism representatives, who presented the collaboration situation of the art and tourism sectors in the Slovenian capital. Ljubljana Tourism acts as a regional tourist destination management organisation for the city of Ljubljana and neighbouring municipalities. Recently, they have started to focus on cultural and art tourism more intensively. On the national level, a marketing plan of cultural tourism for the 2017-2020 period is being developed, and a similar strategy is in development at Ljubljana Tourism. In Ljubljana, the year 2018 will be dedicated to cultural tourism, as it is also the European Year for Cultural Heritage. Therefore, Tourism Ljubljana is currently in the middle of the first intensive set of meetings with representatives of art and culture related organisations and venues. In these debates, Tourism Ljubljana is focused on stakeholder's coordination of identification and interconnection of art and tourism services. After the initial quest for means of informing tourists about the available art and culture offers and eventual special deals for tourists, the next challenge is finding opportunities for proactive involvements of artists in tourist products. In such quests and challenges, Tourism Ljubljana is still looking for a 'common language' to be able to discuss the possible associated business models that consider the specifics of both the art and the tourism sectors and feasible ways to monetise joint activities. In this sense, the Japanese cases show how the Ljubljana Tourism can engage in negotiating and planning with art representatives. 


\section{Ana Desetnica Street Art Festival}

Aside from the destination level of the mutual synchronisation of art and tourism, we tried to identify actual examples that already include or are planning a more intensive involvement of artists in existing tourism products. The first analysed art-related organisation is Ana Monro Theater. According to the representatives, their main annual event is the Ana Desetnica street art festival organised in Ljubljana (and to a lesser extent also in other places around Slovenia), where within a few weeks numerous art groups from around the world attract over 25,000 visitors. The event, taking place on the streets of Ljubljana, affects the whole city and its entire tourism sector. Due to its significant influence, the Ljubljana municipality partially funds it. Currently, the festival does not intensively include any tourism-related bundled offers, but in 2015, the Ana Monro Theatre created its first tourist product, the so-called 'tourist street-theatre walkabout.' It is a combination of artistic expression and storytelling of the history of the city of Ljubljana, where tourists take part in a re-enactment of scenes staged in historic streets and buildings, including a 2nd World War shelter, where they interchangeably find themselves as spectators and as actors in the show.

\section{Slovenian Railways Vintage Train}

Another tourist example with (not yet realised) art potential, analysed through an interview, was riding on a vintage train; the route takes tourists through the most scenic train route in Slovenia, organised by Slovenian Railways, the national train company, and $\mathrm{A} \mathrm{BC}$ renta-car and tourism d.o.o, a local tourism provider. On the train, at stations and at places nearby the stations, tourists are served authentic culinary samples. Several scenes are played by actors in historical costumes presenting the history of Slovenia and the history of the picturesque section of the railway line, including local natural and historical attractions. This product has been well established (3,500 passengers annually, 60\% foreign guests), but its artistic component focuses only on short historical scenes. Organisers aim for greater involvement of tourism services along the route, which is partially realised through winery visits and tours of natural and cultural attractions. An additional chal- lenge for them remains the more active involvement of local artists and craftsmen.

\section{Comparison and Insights}

For the three Slovenian examples, it can be summarised that they still largely deal with the introductory steps in the integration of tourism and the arts, and are not yet as fully integrated as on the Japanese side. Over the past decade, Slovenia has made significant strides in promoting tourism innovation and sustainability (Nakamura, Zakonjsek, \& Krizaj, 2015). In both areas (in addition to technical innovation and environmental sustainability), it is also important to innovate in the field of user experiences and social sustainability, for which art can be a notably significant content and collaboration generator. Slovenian tourism, in general, is not yet exploiting these sources of additional tourism content and new destination management approaches to the extent as presented in the Japanese examples.

\section{Conclusion}

We performed case study analysis and comparatively discussed two Japanese art tourism projects: a promising cultural heritage city with concentrated human and cultural resources, and a sparsely populated countryside with rich nature. From the discussion of projects' actors, interaction venues and regional resources involved in the creation of social value, we propose a framework for the comprehensive understanding of the value (co-)creation among actors in terms of the service-dominant logic ( $\mathrm{SDL}$ ) theory. Through comparative analysis using the framework's 11 attributes organised in the four groups of Why/Who/What/How, we studied the projects' creative actors such as artists and craftsmen and identified the parties serving as collaboration generators and intermediaries at the various integration levels of art project related tourism.

The insights are extended beyond the Japanese context by including in the discussion a comparison with similar cases in the EU country of Slovenia. This part of the study was added as a first test of the broader usability of the approach. Initial concerns were that countries are geographically and culturally so diverse that the gap between them would 
be too wide to enable useful study results. As it turns out, both sides of the study are enriched by the initial findings presented above. For Japan, the Slovenian cases position the Japanese art-related tourism evolution steps as steps in the right direction and as already realised steps that another country is still planning for the future in a similar way. For Slovenia, the experiences of the already developed projects can be of great value in adapting and upgrading them to the Slovenian specifics. Apart from the learning from each other, the projects show similarities that could lead to a potential collaboration and mutual (non-competitive and synergetic) promotion in the future.

This study can provide a basis for a lateral interdisciplinary approach to the study of art-based social value co-creation, as well as important conceptualised knowledge applicable to management methods for art projects involving tourism.

The theoretical basis for this study remains in development. In the near future, we plan to refine the theoretical base and include concepts from the broader field of cultural event tourism. For further validation, we plan to perform richer case studies by applying the framework to additional art tourism cases from Japan and Slovenia, aiming to develop a new approach to destination management, with insights and implications for both scholars and practitioners.

\section{References}

Anderson, L., Ostrom, A. L., Corus, C., Fisk, R. P., Gallan, A. S., Giraldo, M., Mende, M., Mulder, M., Rayburn, S. W., Rosenbaum, M. S., Shirahada, K., \& Williams, J. D. (2013). Transformative service research: An agenda for the future. Journal of Business Research, 66(8), 1203-1210.

Barrett, M., Davidson, E., Prabhu, J., \& Vargo, S. L. (2015). Service innovation in the digital age: Key contributions and future directions. MIS Quarterly, 39(1), 135-154.

Boes, K., Buhalis, D., \& Inversini, A. (2016). Smart tourism destinations: Ecosystems for tourism destination competitiveness. International Journal of Tourism Cities, 2(2), 108-124.

Callaway, S., K., \& Dobrzykowski, D. D. (2009). Serviceoriented entrepreneurship: Service-dominant logic in green design and healthcare. Service Science, 1(4), 225240.

Echigo-tsumari. (2017). Echigo-tsumari art field. Retrieved from http://www.echigo-tsumari.jp/eng/about/
Eisenhardt, K. M. (1989). Building theories from case study research. Academy of Management Review, 14(4), 532550.

Getz, D. (2008). Event tourism: Definition, evolution, and research. Tourism Management, 29(3), 403-428.

Hamel, G. (2006). The why, what, and how of management innovation. Harvard Business Review, 84(2), 72-84.

Helguera, P. (2011). Education for socially engaged art: A materials and techniques handbook. New York, NY: Jorge Pinto Books.

Kitagawa, F., Breslin, L. \& Fravell, A. (2015). Art place Japan: The Echigo-Tsumari Art Triennale and the vision to reconnect art and nature. New York, NY: Princeton Architectural Press.

Korez-Vide, R. (2013). Promoting sustainability of tourism by creative tourism development: How far is Slovenia? Innovative Issues and Approaches in Social Sciences, 6(1), 77-102.

Krizaj, D., \& Horvat, E. (2015). Assessing innovation potential in Slovene culinary events. Academica Turistica, 8(2), $75-84$.

Kvale, S. (2007). Doing interviews. Los Angeles, CA: Sage.

Letaifaa, B. S., Edvardsson, B., \& Tronvollc, B. (2016). The role of social platforms in transforming service ecosystems. Journal of Business Research, 69(5), 1933-1938.

Lusch, R., \& Vargo, S. L. (2014). Service-dominant logic: Premises, perspectives, possibilities. Cambridge, England: Cambridge University Press.

Maciver, R. M., \& Page, C. H., (1949). Society: An introductory analysis. New York, NY: Holt, Rinehart and Winston.

Mair, J., Robinson, J., \& Hockerts, K. (2006). Social Entrepreneurship. New York, NY: Palgrave Macmillan.

Makiguchi, T. (1964). The philosophy of value. Tokyo, Japan: Seikyo Press.

Nakamura, K. (2013). Modeling of service value creation based on multidisciplinary framework. In M. Kosaka (Ed.), Progressive trends in knowledge and system-based science for service innovation (pp. 44-67). Hersley, PA: IG I Global.

Nakamura, K., Zakonjsek, T. H., \& Krizaj, D. (2015, 9 April). Service-Dominant Logic in the 'O-motenashi'-style value co-creation (the 3 rd report): An insight from the innovative cases in tourism \& accommodation service directed by в т Ps Slovenia. Paper presented at the 3 rd National Conference of the Society for Serviceology, Kanazawa, Japan.

OECD. (2014). Tourism and the creative economy. Paris: OECD. Peng, K., \& Lin, P. M. C. (2016). Social entrepreneurs: Inno- 
vating rural tourism through the activism of service science. International Journal of Contemporary Hospitality Management, 28(6), 1225-1244.

Porter, M. E., \& Kramer, M. R. (2011). Creating shared value. Harvard Business Review, 89(1/2), 62-77.

Prahalad, C. K., \& Ramaswamy, V. (2004). Co-creation experiences: The next practice in value creation. Journal of interactive marketing, 18(3), 5-14.

Rasoolimanesh, S. M., Ringle C. M., Jaafar, M., \& Ramayah, T. (2017). Urban vs. rural destinations: Resident's perceptions, community participation and support for tourism development. Tourism Management, 6o, 147-158.

Setouchi-artfest. (2017). Art Setouchi. Retrieved http:// setouchi-artfest.jp/en/about/

Shirahada, K., \& Fisk, R. (2011, 2-5 June). Broadening the concept of service: A tripartite value co-creation perspective for service sustainability. Paper presented at the 12th International Research Symposium on Service Excellence in Management (QUIS), Ithaca, NY.

Stickdorn, M. (2014). Service design: Co-creating meaningful experiences with customers. In S. McCabe (Ed.), The Routledge handbook of tourism marketing (pp. 329-344). New York, NY: Routledge.
Throsby, D. (1994). The production and consumption of the arts: A view of cultural economics. Journal of Economic Literature, 32(1), 1-29.

Throsby, D. (2001). Economics and culture. Cambridge, England: Cambridge University Press.

UNESCO. (2017). UNESCo world heritage and sustainable tourism programme. Retrieved from http://whc.unesco .org/en/activities/669/

Vargo, S. L., \& Lusch, R. F. (2015). Institutions and axioms: An extension and update of service-dominant logic. Journal of the Academy of Marketing Science, 44(1), 523.

Vargo, S. L.,Wieland, H., \& Akaka, M. A. (2015). Innovation through institutionalization: A service ecosystems perspective. Industrial Marketing Management, 44(1), 63-72. Yin, R. (2009). Case study research: Design and methods (4th ed.). Thousand Oaks, cA: Sage.

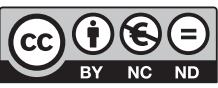

This paper is published under the terms of the Attribution- NonCommercial-NoDerivatives 4.0 International (CC BY-NC-ND 4.0) License. 